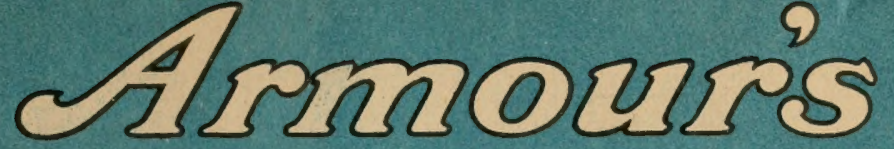 MUND 且OOK \\ OF AGRICULTURE
}

521 A7 Copy 1

BET TER LIVESTOCK

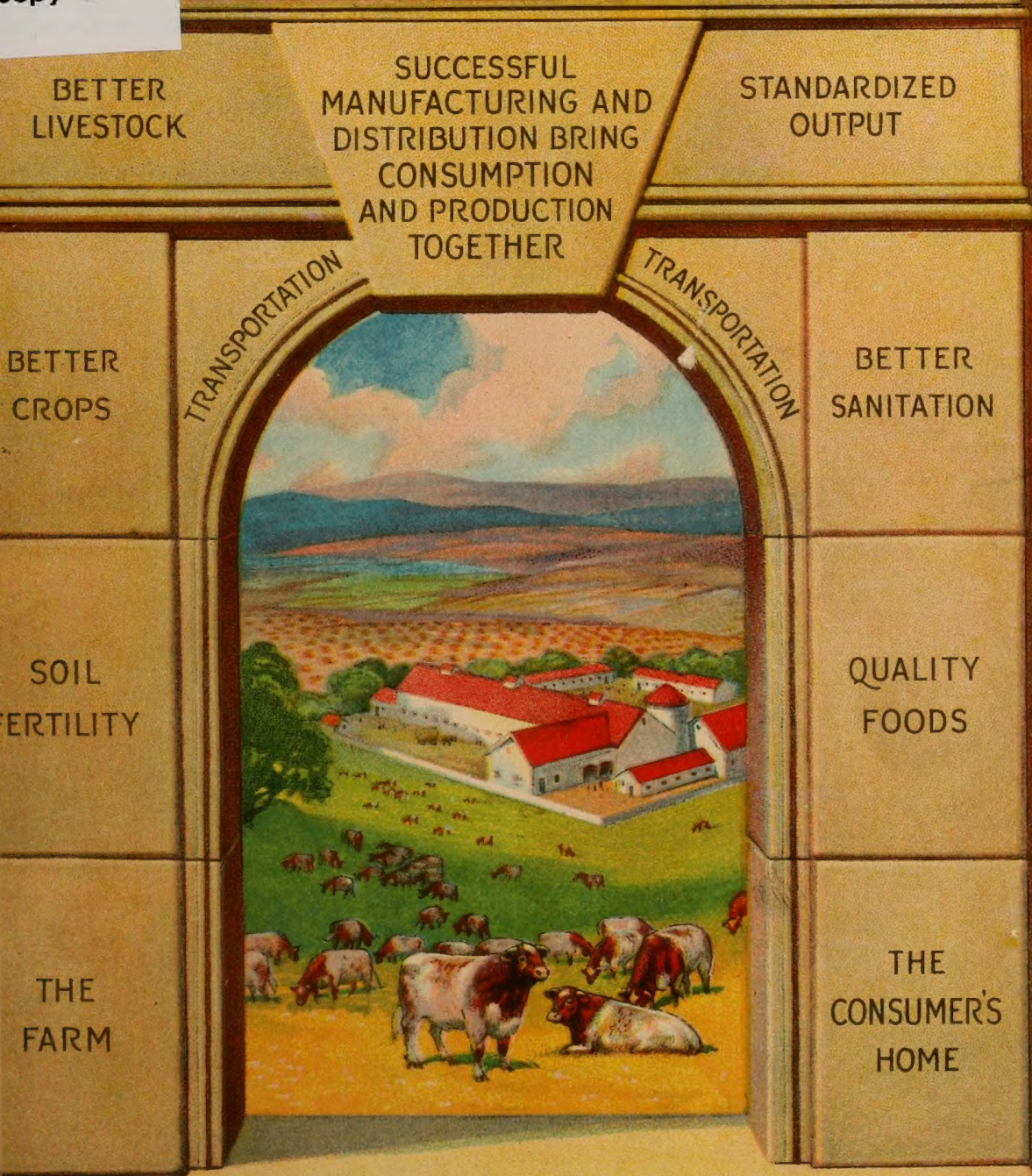

THE ARCHWAY THAT LEADS TO SUCCESSFUL FARMING

- ARMOUR'S - BUREAU - Of *

- AGRICULTURAL · RESEARCH - AND - ECONOMICS R.J.H.De Loach, Director 



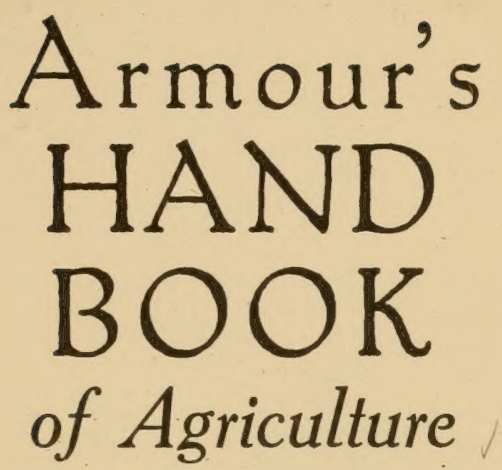

Published, January, 192I

$$
\vdots \vdots
$$

Armour's Bureau

of Agricultural Research and Economics

R. J. H. De LOACH, Director

Union Stock $\Upsilon_{\text {ards }}$

Chicago, Ill. 
"America's greatest need to-day is a more complete understanding of her industries in their relation to agricultural production and prosperity.

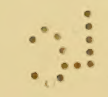

(C) $01 A 615217 \mathrm{C}$ 


\section{J. OGDEN ARMOUR}

CHICAGO

Dear Sir:

We are handing you herewith a copy of our Handbook of Agriculture, which defines our relations with agriculture and our position or policy on agricultural and production problems.

We feel that for the best interests of all concerned it is important for us to make a statement of our position on these matters. It is very evident that the proper relation should exist between commerce and industry and agriculture, and it is our aim to have this book help to establish this relationship. We believe that it represents the viewpoint that all of us must come to in the furtherance of our concerted interests and in the development of a more wholesome national spirit.

Very truly yours,

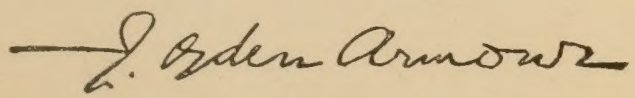





\section{ARMOUR AND THE FARMER}

Within recent years interest in agriculture has been growing very rapidly. Railroads, banks, chambers of commerce, and many large industries have organized departments of agriculture. A new impetus has been given to agricultural education, and agricultural colleges and experiment stations have begun to receive large appropriations and to flourish as they never did before. The farmers are more alert mentally, and are making better use of the soil, which shows a healthy reaction from this universal interest in the subject.

Many factors are back of this new interest in agriculture. In the first place, all are beginning to see that agriculture is the only vocation that can maintain an independent existence. For in it, men can find their food, clothing and shelter, and with these life can be sustained. In the second place, all are beginning to understand the importance of the soil as our universal source of supplies. We are beginning to realize that the soil can be wasted or it can be conserved in a state of permanent fertility, and that universal interest may set machinery in motion to preserve it permanently before the "thinning" process has gone too far.

While agriculture is perhaps the most important vocation of man, civilization is based on successful agriculture, plus a healthy system of transportation, commerce, manufacture and industry. It is based on the proper contact of man with man and nation with nation, which is not possible without an efficient system of transportation. Farmers realize thoroughly that agriculture is a fascinating business or vocation only when to its necessities are added comforts and amusements. They know that to make these possible requires skilled workmen and talent not engaged in agriculture. In other words, civilization requires that populations be so divided that only a sufficient number will be producing to furnish food and clothing, and to make agriculture fascinating; that a sufficient number be engaged in transportation to make for efficiency, yet not so crowded that the vocation ceases to be profitable; that a sufficient number be engaged in manufacture and commerce, and that there be equal chance for life, liberty and the pursuit of happiness in all lines of activity.

Armour is interested in agriculture because it is the background of all manufacture and industry, without which they could not exist. Commerce and industry must prosper with agriculture. They cannot prosper at the expense of agriculture. In the early history of mankind, production was imposed upon slaves, and government was administered to the people and not controlled by them.

For the purpose of getting an accurate estimate of Armour's relations with production, there has been organized a Bureau of Agricultural Research and Economics. To this department we are looking for a thorough investigation of our interest in the problem, and just how we should establish closer relations with the producers. This book shows some points at which Armour and the farmer have interests in common and we believe will lay the foundation for an understanding of our problems, and for a better relationship between our interests and the farmer's interests. 


\section{THE GOVERNMENT AND THE FARMER}

The Government, it should be kept in mind, is not any particular material thing, but is the embodiment of the spirit or soul of a great mass of people, and is represented by a class of citizens called government officials or employès. The fairness with which this spirit is administered depends upon the natural ability, the training and personal peculiarities of these representatives.

Men are not perfect, whether they be in office or out of office, whether they be in public positions or private business. Fallible men out of office do not become infallible men in office, and for these reasons, representatives of the spirit of the whole people may not always be free from prejudices. The idea of loyalty to the Government is based on the assumption that men out of office are as anxious as men in office to obsierve the law and to see that the Government shall function properly and that public officials shall represent the spirit of the whole people rather than that of any particular class.

The United States Department of Agriculture represents the entire nation agriculturally, not a particular class of citizens called farmers. No government can have a more important work than to foster the production of a sufficient amount of food, clothing and shelter for its citizens, and to encourage and protect against fraud those who are engaged in agricultural pursuits. The nature of its work seems to indicate that it is perhaps the most important department of our Government.

The Department of Agriculture has evolved the greatest piece of agricultural machinery of its kind in the world, and when properly functioning should inspire our farming population to develop the highest degree of efficiency. To accomplish this, millions of our general tax money are spent annually and thousands of experts are employed. To discover means of producing more bread and meat on a given surface, and with this to promote the welfare of the producers, is the Government's primary interest in agriculture.

This great Department represents the spirit of America agriculturally only when it exercises a wholesome leadership with the proper attitude toward all the people. In a democracy no department of government can, with safety, promote one line of business at the expense of others. There is great danger in prejudicing one class of citizens against another, which we hold is never justifiable in a governmental agency. To do so is a sign of weakness or unfairness on the part of those who, for the time being, have in charge the administration of the affairs of government. The function of the government should be rather to exercise leadership, to harmonize differences and to warn and punish offenders.

The packing industry is very closely related to, and its growth, for the past half century, has been coexistent with the development of our agriculture. It is founded on sound economic principles, and in a study of these principles the industry asks from the Government only the same fair dealings as are accorded other industries and vocations, including agriculture.

Our Federal Government is divided up into many parts, and each 
division is charged with a certain duty. For a Department to try to function outside its own sphere is likely to lead to misunderstanding and serious consequences. When the Department of Agriculture is making investigations in the field of Commerce and Manufacture, it seems that the natural thing would be to do so in conjunction with the Department of Commerce, just as the Department of Commerce would be expected to do in the case of making inquiry regarding agriculture.

This industry is engaged primarily in the manufacturing and marketing business, not in agricultural production, and marketing is the first step in the field of commerce, and its importance is second only to that of agriculture. Farmers, we believe, should co-operate in the marketing of their products to the same extent to which others are permitted to co-operate, but when the Government promotes anymarketing problem it should represent the spirit of all the people, rather than the welfare of any particular class. The Department of Commerce should be the umpire for the Government in all matters pertaining to the marketing of all products, both those of the farms and those of the manufacturers, and the subject should always be considered as a whole and the welfare of all the citizens taken into account in every step of the marketing process.

\section{THE STATE AND THE FARMER}

The State is a step nearer the lives and homes of the people than is the Government, and enters more into sympathetic relations with them because State officials are seen oftener, and become a reality in the minds of the people. The State's interest in agriculture is similar to the Government's interest, - but it has a more direct way of expressing this interest.

The states promote the business of agriculture in many ways including the services through the Department of Agriculture, the Agricultural Colleges and Experiment Stations, and the teaching of agriculture in the common schools. In all these, the idea is to help develop thrift on the farm, and to insure good returns from the soil. The State finds that the promotion of agriculture is good insurance against the day of want. In promoting agriculture the State should not overlook the welfare of all other activities. It is promoting agriculture for the benefit of the entire state, and not merely for the farmers.

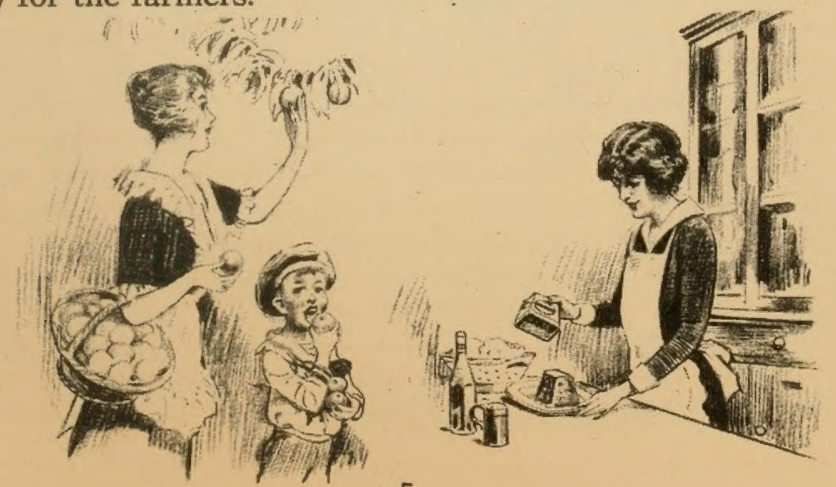




\section{AGRICULTURE AND INDUSTRY}

The greatest problem in ancient times was to keep enough men producing on farms so that those not on farms would have food and clothing. This is not true today, because of the development of the principle of landownership, and the new business of farming which will keep a safe ratio on the farm.

The progress of agriculture depends as much upon the number and kind of people who are not on farms as it does on those who are on farms. If all were farmers, every man would produce what he needed and would consume what he produced. He would not need to buy and there would be no one to sell to, so there would be no advantage in producing a surplus. It is extremely important, therefore, for the safety of agriculture that we have a sufficient number of the right kind of citizens off the farms to properly handle our industries, our manufactures, and our commerce, and to consume the surplus products of our farms. Farming can be made profitable only when farmers can sell enough products to buy land and the necessary farm equipment, and to enjoy the comforts of a progressive civilization.

While agriculture, therefore, may be the most important business of the nation, industry also is highly important and necessary. Civilization is based on a healthy development of manufactures, a great system of transportation, and the growth of commerce. A large percent of the population is required to do these things other than farming, and farming can be made a business only when there are many other lines of business and when farmers have a maximum number of customers. At present about 49,000,000 people are living on farms in the United States and her possessions, and nearly 59,000,000 off the farms. This makes approximately $42 \%$ of the people on farms and our farmers have a market for about $58 \%$ of their total products. Industry, which has become necessary to manufacture, conserve, and distribute this surplus, furnishes a market for farm produce that converts agriculture into a business second to none in the country.

The business of agriculture may be conducted economically on a small scale, or in small units, but for most other kinds of industry this is not possible. Business and industry have found that organization on a large scale develops efficiency and cuts down overhead expenses. Some think that the future success of our agriculture will depend on organizing on a large scale, and in this way fall in line with the standards set up by large industrial organizations. Whether this be true will depend on the will of the landowners themselves. Farms are growing larger and farmers are organizing for the successful marketing of their products. This is in keeping with the marketing of manufactured products by organized business. In developing this idea, farmers should not ignore the fundamental law of supply and demand, which determines whether a given product brings a good price or whether it must be sacrificed. Industry has learned that prices are set by demand for a product, and not by the will of those who would sell. 


\section{RATIO OF RURAL TO URBAN POPULATION}

In the foregoing it is shown that about $49,000,000$ people live on farms in the United States, while approximately $59,000,000$ live in cities and towns. To secure the necessities of life from the earth requires a greater number of our citizens than any other single vocation, and there are enough citizens not on farms to make a large ready market for this produce. To this fact alone can be attributed the possibility of making of our agriculture a great industry or business. It is what farmers eat that keeps them alive, but it is what they sell that makes them thrifty and prosperous.

It is frequently asked if we need more farmers and greater competition in the field of agricultural production? From the standpoint of the farmer, the answer would be NO! Farmers frequently need more labor on the farm, but they are not anxious to have a greater number of farmers. From the standpoint of the consumer, the answer would be YES! The consumer is looking for cheaper food, while the farmer is looking for higher prices for his products. This conflict of desires is natural, and is brought about largely by the ever changing ratio of country-city populations.

In the early days $5 \%$ of our population lived in towns and cities, and the other $95 \%$ on farms. Only those thrifty farmers located near the towns and cities marketed anything, while those more remote produced only a sufficient quantity to supply their own needs. This condition was generally true until the invention of the spinning jenny and the settlement of the fertile lands in the middle west. From this time, production became a less serious problem, and our clothing and shoe manufacturing establishments began to grow upon the eastern shore. Our transportation systems began to reach for raw produce, and to take products to consumers.

The tendency, therefore, has been to drift from the farms to the cities, as our manufactures have grown and our transportation systems have removed the danger of starvation from centers of population. What is the limiting ratio? How many more can we spare from the country? These questions can be answered only by the limit to which farm machinery can be improved, and by the prices of farm produce. It also depends upon the extent to which other vocations become crowded. When the competition in our industrial centers becomes too great, the people will move to the country, and when the prices of farm products are too low, farmers and farm labor will move to the towns and cities. We believe the natural laws of landownership and the fascinating vocation of agriculture will keep this ratio within the safety limit.

Farmers sometimes believe there are too many middle-men. Yet what are middle-men to do unless they function as they are? Shall they be sentback to the farms to compete in production? There has always been a certain amount of dead timber both on farms and in cities, but their burden is carried by society as a whole, not by producers alone. The man who pays the bill at the other end of the line carries the most of it. If the consumer paid less, the producer would get less, as in our present state of society. The redeeming feature is that every person not a producer is a customer. 


\section{THE NATURE OF OUR AGRICULTURE}

Ours is a livestock agriculture, a fact which makes the livestock market an essential ally of the farmer and an important factor in our agricultural system.

In the year 1919 we fed approximately $80 \%$ of all our grain crops to livestock, making the immense total given below:

\begin{tabular}{|c|c|c|c|c|c|}
\hline $95 \%$ & of our & oats. & or & $1,152,970,000$ & bushels \\
\hline $90 \%$ & 61.68 & corn & $\because$ & $2,533,887,000$ & “6 \\
\hline $85 \%$ & 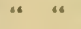 & barley & $“$ & $184,720,400$ & “ \\
\hline $30 \%$ & *4 & wheat & “ & $384,203,000$ & " \\
\hline $20 \%$ & "4 4 & rice & "s & $31,865,000$ & “ \\
\hline
\end{tabular}

The greater part of our farm lands was given over to the growing of feedstuffs for livestock, which have added proportionately to our necessities, comforts and luxuries. This method has enabled the American farmer to convert into money the entire output of our national agriculture. If we had no livestock industry, there would be such a large surplus of grain that all the world could not consume it.

The most important factor in the development of this system of agriculture has been a ready cash market for livestock. Before such a narket was established, our agriculture was at a low ebb, but since then it has far outstripped any other in the world.

The country has grown into great farming centers and manufacturing centers, as a result of its geography. There are large areas of fertile soil in the middle west, and natural advantages for manufacturing and export trade on the Atlantic seaboard. This has resulted in areas of overproduction and sections of overconsumption.

For instance, in 1918 the State of South Dakota shipped out, on the hoof, 600,000 beef cattle and $1,700,000$ hogs, to be manufactured into food products by the large packing plants, to be taken east for distribution, and to return large sums of money as farm income. Iowa, Illinois, Missouri, Indiana, Ohio, Nebraska and Georgia have $50 \%$ of the hogs of the country, or a total of $35,000,000$. Texas, Nebraska, Jowa, Kansas and Illinois have $25 \%$ of the beef cattle, or a total of $11,000,000$. This book is prepared partly for the purpose of showing how these sections have been brought together.

The equipment of the packing industry has been gradually adjusted to the need of doing this very thing, and was not from the first destined to enter into competition with the smaller slaughtering houses. This is the explanation of an immense system of mechanical refrigerator cars. To haul live animals such distances would be more than four times as costly. 


\section{HelpYourself by Helping Each 0ther}

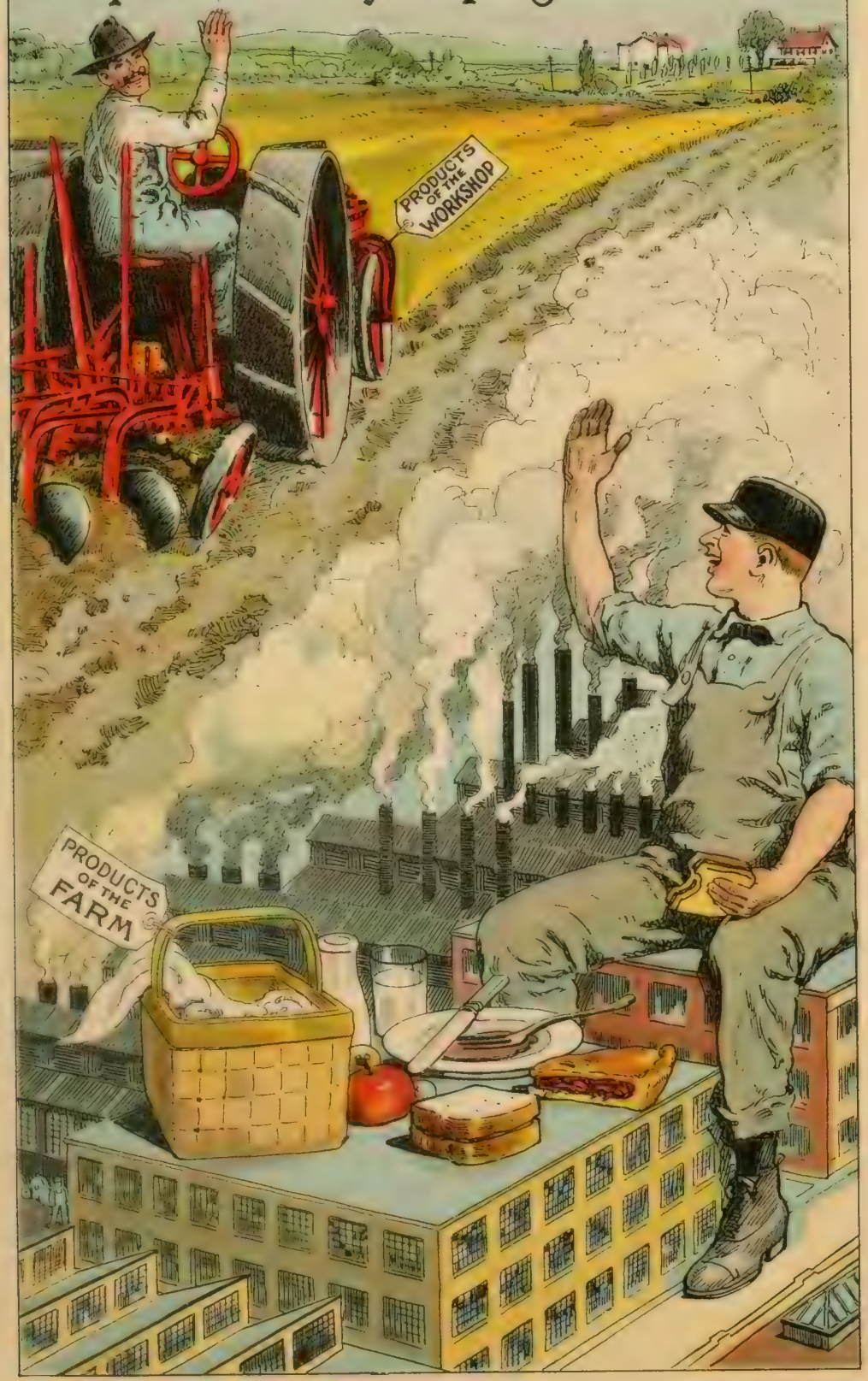




\section{MARKETING OF FARM PRODUCE}

No matter how much food our nation as a whole produces, farmers will always have to face the problem of marketing it. Nowhere in the world has a system been developed in which the ultimate consumer goes after the goods he needs and it is extremely doubtful if price levels and decreased production will ever reach a point where a change in the economic scheme will be necessary.

Nearly all businesses in which the production of a definite commodity is the aim, have two separate departments, a production department and a sales department. The two are manned by en. tirely different types of men, each skilled in his own field. It is rare indeed that a member of the production department is a good salesman, and even rarer that a good salesman is a good producer. Hence it is not surprising that farmers have in general failed to combine these two functions in the handling of their farms, and that a complex marketing system for farm produce, adapted to the distances that must be covered from farm to dinner table, has sprung up. In the case of fruits, vegetables and many of the cereals and hays, there is practically no change made from the form in which the product leaves the farm, hence a margin in price is required only for labor in grading and sorting, transportation and waste due to spoilage. Animal products, except eggs and raw milk, require a certain amount of manufacture in addition, hence the farmer requires the service of marketing agents to a greater degree, a service that may cost much more in terms of margin than is required on grains or other farm products.

Farm production is seasonal, but the products must be so handled as to be distributed over the year. With the fruits, grains and vegetables, there is little choice as to what the farmer can do. The middleman has developed storage facilities that are so much cheaper and more efficient than those which the individual farmer can obtain, that it is the usual practice for the farmer to sell at once and thereby make the greatest profit from his crops, even though the prices may be a little higher at some later period. Livestock presents a different situation, however, since its marketing is much more independent of season. The intelligent feeder can so plan his feeding schedules as to market his animals at any time, although he will usually find that the cycle whereby his young animals are born in the spring and fed out on the crops of the following autumn or the second season, give him the lowest cost of production. If he seeks the higher price levels of the light seasons on the livestock market he must match his judgment of probable increased prices against his own knowledge of increased cost of production.

The sale of livestock is the first step in the marketing process, being a trade between the commission man who represents the producer, and the buyer who represents the manufacturer. Both know markets and set their judgment, one against the other, to make a bargain. Due to the variations in judgment in different farmers, there are always going to be a number of dissatisfied losers, and the marketing problem will probably be as acute in 2021 A.D. as it is in 1921 or was in 221, for it is an old, old problem. 


\section{MANUFACTURE OF FARM PRODUCE}

A certain amount of farm produce is consumed just as it comes from the farm, while a great portion is manufactured completely before it is ready for final consumption. The progress of our civilization is measured by our ability to convert raw product into its greatest usefulness to man. Things that do not require manufacturing were as common among savages as they are among civilized peoples, but only the crudest efforts at manufacture were made by man before the dawn of civilization. His growing wants have inspired him to discover how he can better use Nature's storehouse.

The packing industry is based upon the necessity of processing livestock for man's needs. Man ate animal flesh before the days of the packing industry, but largely around the centers of production. There was very little trade in meats and meat products except where farmers brought fresh meats to the villages and towns, to dispose of them for immediate consumption.

In our modern civilization, meat is a large portion of the diet because: 1 . It contains food elements that are most nutritious and appetizing; 2 . The production of livestock fits into any agricultural scheme for conserving soil fertility. The manufacture of livestock into meats by the large packing establishment is differentiated from primitive methods, or even the modern small slaughtering house, by at least two qualifications. 1. It must be sanitary and must pass Federal inspection for cleanliness as well as for the wholesomeness of the meats that are being manufactured. 2. It must have equipment of such nature as to fit into the national development of our agriculture. It must manufacture on a large scale, especially in the United States, must ship fresh meats rapidly from one part of the country to the other, and must have an immense system of refrigeration to keep these meats in perfect condition until they finally reach the consumer.

The manufacture of livestock and other farm produce into the most usable forms has unquestionably been responsible for the progress and prosperity of our agriculture, and agriculture owes to industry much for the part it has taken in helping to increase the value of farm produce. A strictly agricultural country cannot prosper unless a large proportion of the population is engaged in manufacture, commerce and transportation, as well as in agriculture. There might have been a degree of satisfaction in farmers making their produce into usable materials, but few of us would exchange our modern civilization for this primitive condition. In fact, everybody has fostered the modern principle of the manufacture, away from the farm, of farm products into usable materials.

In the development of this system in our country, all classes of labor and industrial management have specialized to a degree far beyond the farmer. Those in our manufacturing centers where it is necessary to have specialized effort can do very few things, perhaps only one thing efficiently. However, they prove a mighty factor in adding value to farm produce before it is ready for final consumption, and it is quite necessary to keep in mind all of these points when we study the problems nearest to us. 


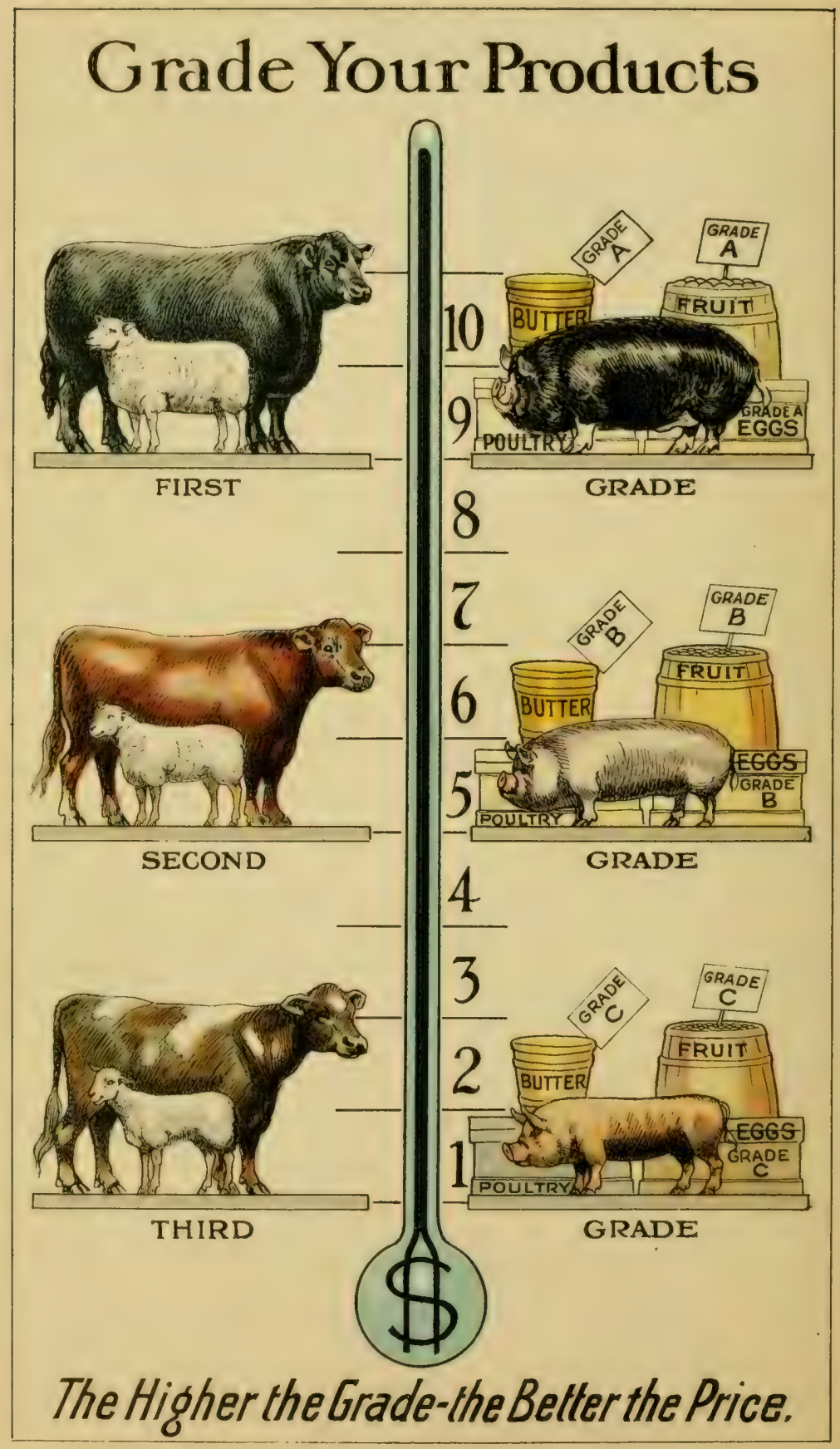




\section{WHOLESALE MARKETING}

The first trade in the marketing process is between two experts, - the commission man and the packer buyer, both knowing the value of the livestock sold. The second step is the sale of the carcass or wholesale cuts by the manufacturer to the retail butcher, again a trade between two experts. Each possesses a full knowledge of the public demand for meat and meat products. The third and last step in marketing is the final sale by butcher to consumer. Whether this is between two experts depends on whether the consumer is a meat expert. In most cases he is not, but he does know when meats suit his taste, and he refuses to patronize butchers who continually offer products that do not appeal to his palate.

We propose to discuss only the problem of the wholesale dealer, as it relates to the distribution of packing-house products. This process requires for fresh meats complete equipment, including large curing houses, elaborate mechanical refrigeration, and an efficient system of refrigerator car lines, and all this in addition to large manufacturing plants, where overhead expenses can be kept down. The success of our agriculture and of all industry, may be traced directly to the quick wholesale movement of the finished product. Unless such products could be moved rapidly and regularly as they are made, the channels of trade would soon be clogged and people would go unfed and unclothed, and the raw products would find no place in the factory experience.

Contrast the early days of handling meats when that which was not consumed immediately was lost, with today, when a large industry saves practically every pound. In the conduct of this business the fundamental laws of values are in operation every minute of the time. The value of the articles offered for sale depends upon the price for which they can be sold. No one can very long maintain his business who cannot produce the articles offered for sale, for less money than he receives for them. The cost of operation plus the cost of the raw products must be more than realized in the sale of the goods, and at the same time the keenest competition must be met. The manufacturer or firm that exercises the best judgment in buying raw products, usually can make the best appeal to the consuming public, beucts that find a broad that are likely to bring cause they appeal to trade.

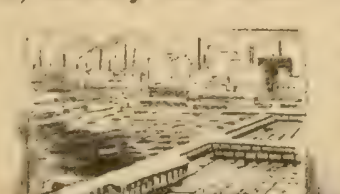
cause he gets the prodand steady outlet, and the better prices bethe better class of

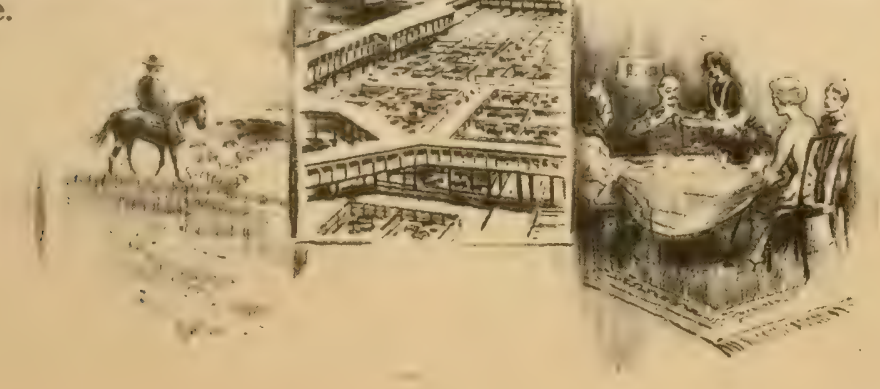




\section{THE DISTRIBUTION OF FOOD PRODUCTS}

The center of livestock production in the United States is approximately 1,100 miles from the center of meat consumption. That the people of the United States do not have to travel this distance to secure their supplies, is due to the efficiency of our industrial and transportation systems: The fact that prices of meat are so nearly national in nature, proves how thorough the distribution is. There is little that is sectional in the way a big packing organization handles its products. For example, two-thirds of the beef slaughtered at Armour and Company's river markets, Kansas City, St. Joseph, Omaha and Sioux City is consumed east of the Ohio borders, an average distance of 1,125 miles. Nearly as great a proportion of the beef from the Ft. Worth plant goes into the southeast, an approximate distance of above 800 miles. The average distance that a carcass of beef travels from the time Armour and Company receive it until it leaves the Company's possession is approximately 450 miles. A lamb carcass travels about 600 miles, and the products from a hog carcass, 500 .

The distribution problem is more than geographical, however. Nearly a!l livestock is fed on the annual cycle based on the dates when crops ripen, while its products are consumed according to the frequency with which man gets hungry. This makes necessary a distribution in time that arouses a second and very important problem in livestock marketing. The great period when cattle and sheep come on the market is in the fall, while hogs come in the winter, principally during the period November to February. On the other hand the summer consumption far exceeds the receipts of that season. Hence the problem of the marketing organizations is to assume the overhead expense necessary to bridge over the lean months and so to handle the receipts as to result in a minimum of discomfort for the great body of consumers in America. During the fiscal year 1918-1919 Armour and Company's sales were distributed according to two-month periods as shown in the following table, while the receipts on the market were as indicated.

PERCENTAGE RECEIPTS AND SALES BY PERIODS OF LIVESTOCK AND MEATS

\begin{tabular}{|c|c|c|c|c|c|c|}
\hline & $\begin{array}{c}1918 \\
\text { Nov.-Dec. }\end{array}$ & $\begin{array}{c}1919 \\
\text { Jan.-Feb. }\end{array}$ & $\begin{array}{c}1919 \\
\text { Mar.-Apr. }\end{array}$ & $\begin{array}{c}1919 \\
\text { May-June } \\
\end{array}$ & $\begin{array}{c}1919 \\
\text { July-Aug. }\end{array}$ & $\begin{array}{c}1919 \\
\text { Sept.-Oct. }\end{array}$ \\
\hline $\begin{array}{r}\text { Beef sales ........... } \\
\text { receipts...... }\end{array}$ & $\begin{array}{l}17.6 \\
22.2\end{array}$ & $\begin{array}{l}19.8 \\
17.6\end{array}$ & $\begin{array}{l}15.1 \\
12.4\end{array}$ & $\begin{array}{l}13.8 \\
13.5\end{array}$ & $\begin{array}{l}16.3 \\
14.8\end{array}$ & $\begin{array}{l}17.4 \\
19.5\end{array}$ \\
\hline $\begin{array}{r}\text { Lamb sales........ } \\
\text { receipts.... }\end{array}$ & $\begin{array}{l}15.2 \\
19.2\end{array}$ & $\begin{array}{l}16.1 \\
13.8\end{array}$ & $\begin{array}{l}14.4 \\
10.0\end{array}$ & $\begin{array}{l}14.4 \\
11.8\end{array}$ & $\begin{array}{l}17.8 \\
18.0\end{array}$ & $\begin{array}{l}22.1 \\
27.2\end{array}$ \\
\hline $\begin{array}{l}\text { Pork sales......... } \\
\text { receipts ....... }\end{array}$ & $\begin{array}{l}15.5 \\
21.7\end{array}$ & $\begin{array}{l}20.9 \\
23.4\end{array}$ & $\begin{array}{l}16.5 \\
15.1\end{array}$ & $\begin{array}{l}14.8 \\
17.0\end{array}$ & $\begin{array}{l}16.2 \\
11.3\end{array}$ & $\begin{array}{l}16.1 \\
11.5\end{array}$ \\
\hline
\end{tabular}

The beef and lamb surplus from September to December and the pork surplus from November to February, are clearly demonstrated. 


\section{CONSUMPTION}

Food consumption is based fundamentally on the need of energy and of replacing the worn tissues in the individual. However, civilization has carried it far beyond such a point, and today food consumption is based not on needs, but on the appeal of quality, flavor, sanitation and general appetizing conditions of marketing. The proportions of different foods or the general character of foods is a racial matter, or, within the race, a family matter. It is generally known that the peoples of the northern latitudes consume more fats and that the peoples of the tropics more fruits than those of the temperate zones. It is less generally known that the bulk of mutton and lamb produced in the United States is consumed east and north of the Ohio-Pennsylvania Southern state line and the Potomac River. Each section has its food peculiarities and each city or market within that locality its individual characteristics. It is difficult to appreciate in terms of pounds how cities with strong Catholic populations reduce their meat consumption on Fridays, or what a factor the feast days or fast days observed by members of other religions are in the movements of farm produce. Moreover, some communities express preferences for one cut, some for another; witness the Jewish abstention from pork and the consumption of fore quarter beef. The meat salesman has to anticipate these days and customs, while the general vendors of farm produce must understand them perfectly, else there is great waste.

But even greater than these fixed days in determining the rate of consumption of the different foods is the effect of weather on the tastes of the public or the effect of competing foods. It is difficult indeed to measure the effect of a few carloads of early strawberries or melons on meat consumption, not because they are competing foods from a nutritional standpoint, but because they compete for the favor of the limited family purse. Few farmers are competent to judge these whims of taste, and the services of highly trained middlemen are therefore necessary to guarantee the farmer highest prices for his products.

The differences in nations as to annual per capita meat consumption is shown in the following table, prepared from data furnished by the U. S. Department of Agriculture in 1916:

\begin{tabular}{|c|c|c|c|}
\hline 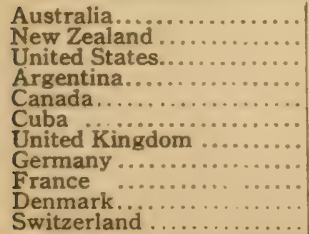 & 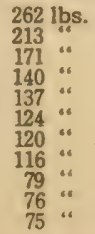 & 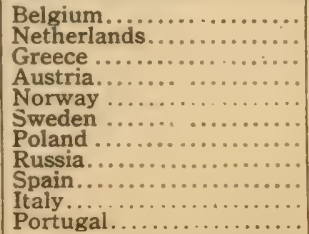 & 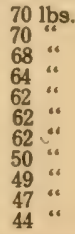 \\
\hline
\end{tabular}

It will be noticed that the English speaking countries are by far the biggest consumers of meat, while there are no Asiatic races given in the table. This is because the Asiatics are very frugal consumers of meat indeed, Japan being the only nation that shows any signs of increasing in this particular. 
SERVING ANL

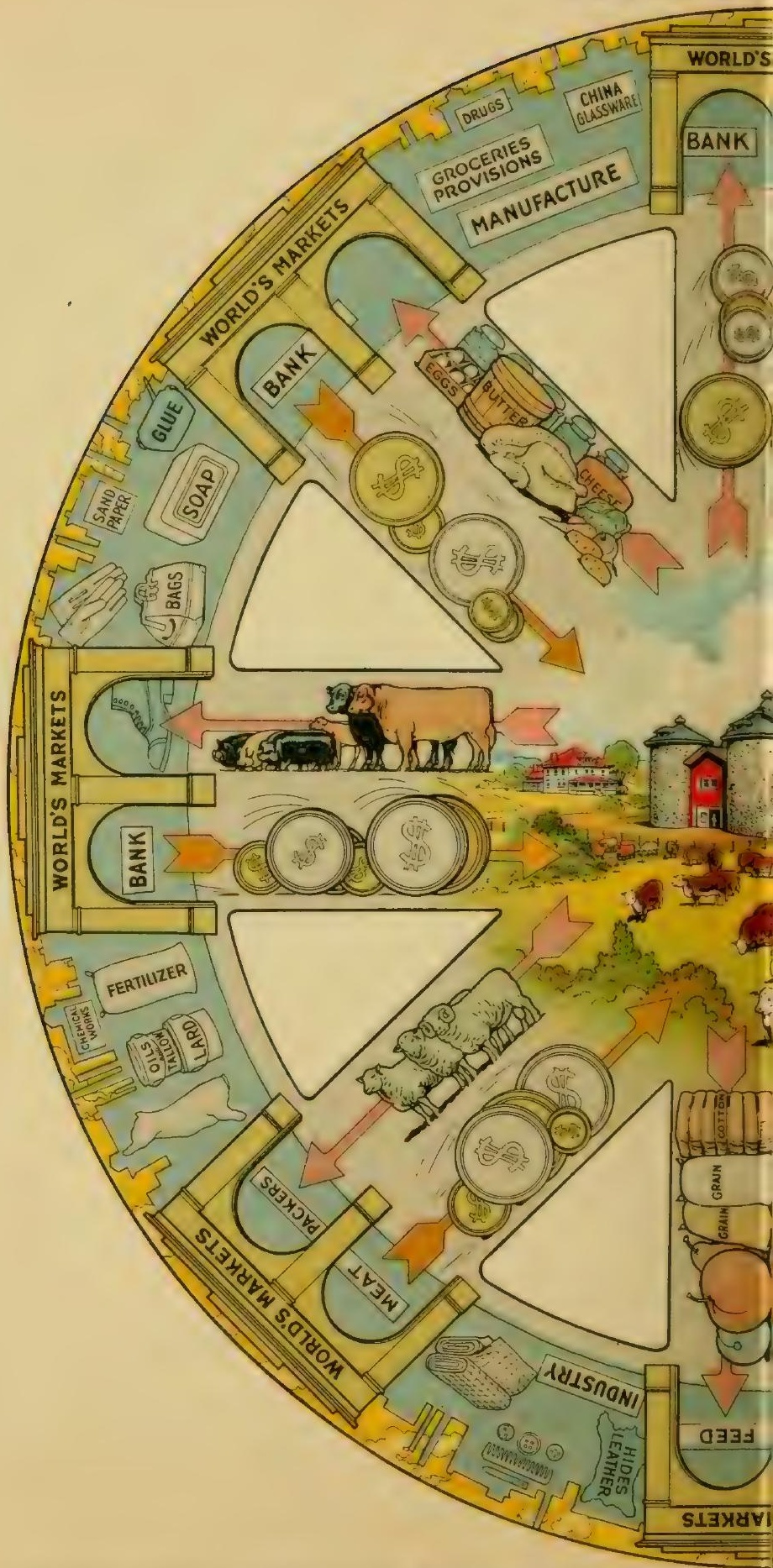




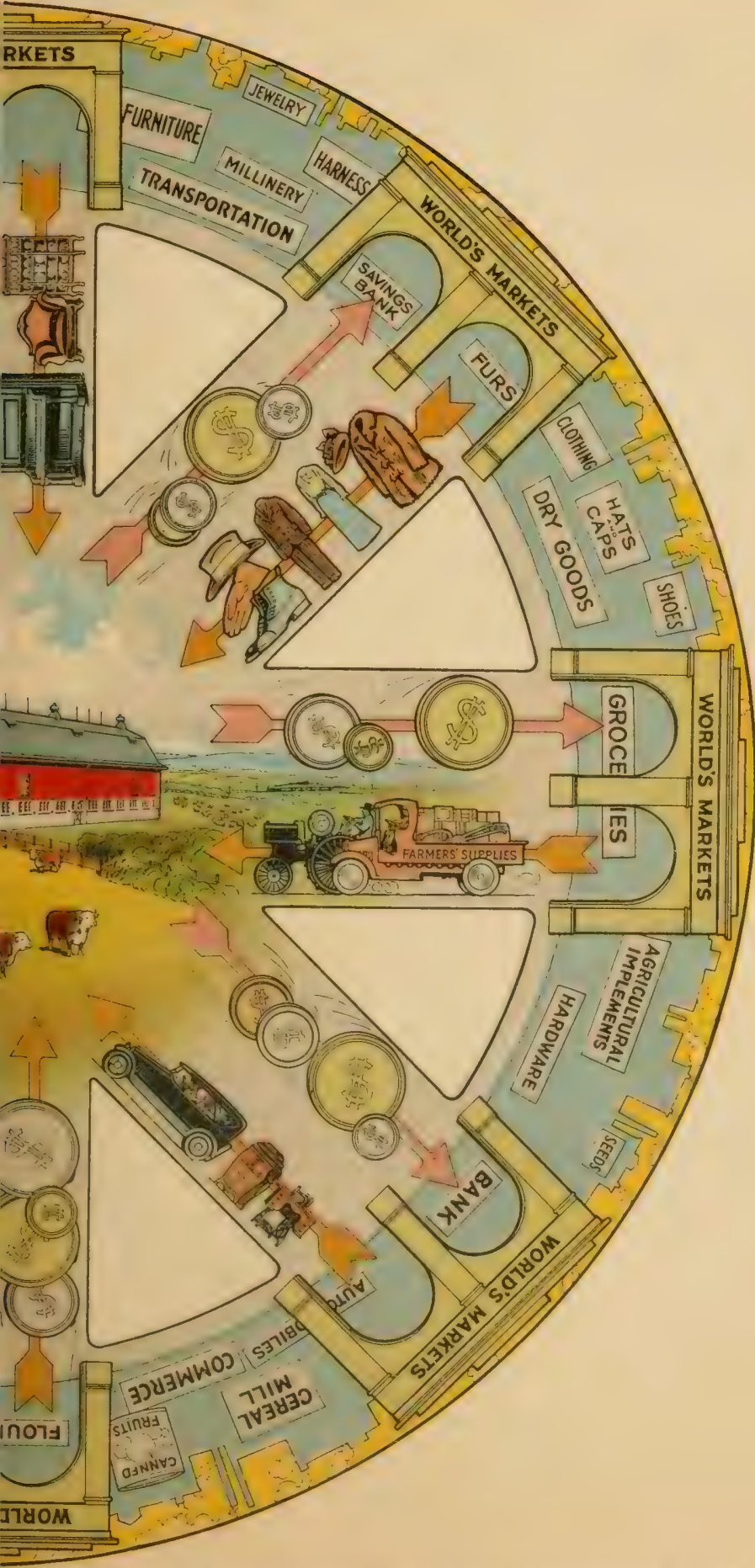

OPERLY ORGANIZED, WILI, STAND TOGETHER FOR AL EFFICIENCY 


\section{THE CENTERS OF POPULATION. THE GREAT PROBLEM OF DISTRIBUTION}

The great centers of population in the United States are along the Atlantic seaboard and inland for about a depth of 300 miles. Excluding the Gulf States, Florida, the Carolinas and Ohio, this includes about 32 percent of the population, all of which is characteristically industrial, and hence a food consumptive group. Not all other regions are surplus producers as far as all classes of meat are concerned, the southeast, for example, requiring the shipment of a large proportion of its beef and lamb, and the northwest and southwest a large part of their pork and pork products. Nevertheless, the great problem in distribution is furnished by the eastern centers, and the accomplishment of this function is the economic reason for the existence of national packing organizations.

We believe that Armour and Company's figures on distribution from the various sections in which their plants are located are sufficiently representative of the economic facts of distribution to be applicable to all national packing companies, and that they will give a typical measure of the contributions of each of the producing districts toward feeding this third of our population located in industrial regions. The following table is self-explanatory:

\begin{tabular}{|c|c|c|c|c|}
\hline \multirow{2}{*}{ PLANT } & \multicolumn{2}{|c|}{ BEEF SHIPPED } & \multicolumn{2}{|c|}{ PORK AND PORK PRODUCT SHIPPED } \\
\hline & East & Elsewhere & East & Elsewhere \\
\hline 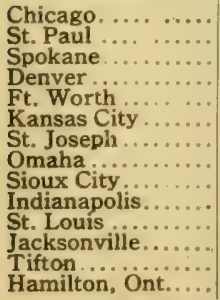 & $\begin{array}{l}61 \% \\
25 \\
2 \\
14 \\
27 \\
63 \\
78 \\
66 \\
62 \\
11 \\
61 \\
0 \\
0 \\
5\end{array}$ & $\begin{array}{l}39 \% \\
75 \\
98 \\
86 \\
73 \\
37 \\
22 \\
34 \\
38 \\
89 \\
39 \\
100 \\
100 \\
95\end{array}$ & $\begin{array}{l}98 \% \\
20 \\
1 \\
0 \\
0 \\
40 \\
60 \\
50 \\
70 \\
0 \\
20 \\
0 \\
0 \\
0\end{array}$ & $\begin{array}{l}2 \% \\
80 \\
99 \\
100 \\
100 \\
60 \\
40 \\
50 \\
30 \\
100 \\
80 \\
100 \\
100 \\
100\end{array}$ \\
\hline
\end{tabular}

Mutton and lamb in general in their distribution tend to follow cattle, although the ratio is not exactly the same. It will thus be seen that the great burden of feeding America's centers of population is laid on the Mississippi-Missouri River section, to the north of their confluence. The shortage in beef in the southeast is largely supplied from the Ft. Worth and St. Louis territory. Pork product throughout the southwest is supplied from the Fort Worth and Denver territory, and throughout the northwest from the St. Paul, Denver and Spokane regions. Because of the arrangement of railroad trunk lines, it is almost as easy to take the meats east as it is to distribute to these more sparsely settled areas, hence it frequently happens that the cost of distribution eastward is relatively much less than it is in the mountain states, the range country and over parts of the Pacific coast. This fact helps to bring up the price of livestock for the western producers and to furnish and lower costs of fresh meats to eastern consumers. 


\section{SOME DIFFICULTIES IN DISTRIBUTION}

The distribution of meats in the United States having been developed according to the scheme indicated, it has become imperative that nothing happen to interfere with the steady flow from day to day, lest starvation conditions develop in the industrial regions. Such an incident as the switchmen's strike of the spring of 1920 is one of the most demoralizing things that can occur in the livestock and meat trade, since the cutting off of further immediate sources of supply boosts the price of available meats due to the strong competitive demand, and the cutting off of further marketing knocks the bottom out of livestock prices, both during the strike and the following period of the rush to market. Unless the steady flow is maintained from day to day in the channels of trade, the situation becomes alarming for the consumer and ruinous for the producer. It is the fluctuation in prospect of flow, as it affects the ratio of supply to demand, that causes the fluctuations in price, so irritating to producer and manufacturer.

A second class of difficulties in distribution arises from the fact that certain portions of the animal find a greater demand and quicker sale than other portions. During the spring and summer of 1920, there was little demand for hides or pelts, and there accumulated hundreds of thousands of dollars worth of such articles on the basis of normal demand that were valued on the 1920 market at only a fourth to one-half their previous price. These had been credited to the beeves or sheep from whose backs they came as far back as February of that year, at the market value on the day the animals were killed, but the falling markets piled up heavy losses while storage charges continued to accumulate. Farmers all over the country were suffering from the same condition with regard to their wool, and the difficulty in handling hides and pelts was reflected in the prices in both classes of stock.

These conditions are abnormal. There exist several phases of normal meat marketing that bring up similar problems. For example, the most difficultly satisfied demand for Armour and Company's cured pork products is for Star bacon and hams. Star bacon can be made from only one class of hogs possessing a certain type and degree of quality. Their sides are only 8-9 percent of their weight, and the number of hogs of this quality is sufficiently small to reduce the figure much lower in comparison to the total kill of fresh pork for the year. If both, bacon and hams of the best grade, are lumped together, they are only about 8.4 percent by weight of the total hog kill. The condition is similar in other classes of animals, the cuts in greatest demand from cattle averaging only 14.3 percent of the live weight and from sheep and lambs only 31.2 percent. This makes the problem of distribution a matter of getting rid of the less popular portions of the kill, 88 percent of the hog, 85.7 percent of the cattle, and 68.8 percent of the sheep. The ordinary method is to make the popular cuts carry what is lost on the less popular, but this is many times impossible when no market exists at all, when numerous cured cuts such as fat backs have to be rendered for lard after the expense of curing has been gone through. 


\section{WHO ARE PRODUCERS?}

The man who can take one kernel of corn and produce 300 kernels has rendered less service than the man who can produce 600 kernels under the same conditions. The feeder who changes one bushel of corn into 10 pounds of pork produces and deserves more than the man whose bushel of corn returns but 7 pounds.

In like manner, a firm which can change a steer into 500 pounds of meat and 50 pounds of hide has rendered a service; the firm which can take the same steer, produce the same products, save an additional $\$ 10$ worth of by-products and distribute each article to that market which wants it most, has served and produced still more. If the service rendered is sounder and more economic than its rival's, the business grows and prospers.

Our national business system consists of a continuous chain of producers from the soil to the ultimate consumer, and the packing industry is unquestionably a very important link in this chain. Essential producers may be divided into two classes, primary and secondary. Those who work with or in the soil belong to the former class, while those who manufacture and distribute are the secondary producers. The first class is composed principally of farmers, miners and lumbermen, whose work is largely done in the rural districts. The second class of necessity live mostly in cities. Factories produce usableand eatablecommodities; railroads produce transportation; merchants produce service and accommodations; banks produce a stable and convenient system for financing; theaters produce amusement, and so on. Community, national, and world prosperity today depend upon the successful coördination of both classes of producers and their products.

Unfortunately, there are people in the country who destroy rather than develop, who rob rather than serve, who take from the land resources that belong to the future. Similarly, there are city dwellers who produce nothing, who render no service, who snatch their living from others. Such people class with their fellow wasters in the country, and all communities would be better without them.

Success, be it in growing hogs, curing pork, or baking hams, depends upon the energized ambition to do the job more efficiently each day, to profit by both past mistakes and successes, to add to one's resourcefulness while earning a living.

A better known and better liked product and a lower production cost are the aims of the manufacturer. The farmer works toward the same goal. Crop rotations and livestock increase current profits, improve the soil and lower production costs.

It is the function of Armour and Company to change the products of pasture and feed lot into usable and eatable commodities, find the outlet for these goods and to distribute each article to its market. Our success depends upon maintaining an accepted and desired quality of goods, and upon practicing the greatest possible economy of time, labor, and product in its manufacture. Our right to live depends upon our ability to do this work in a way to meet competition by a constantly growing efficiency. 


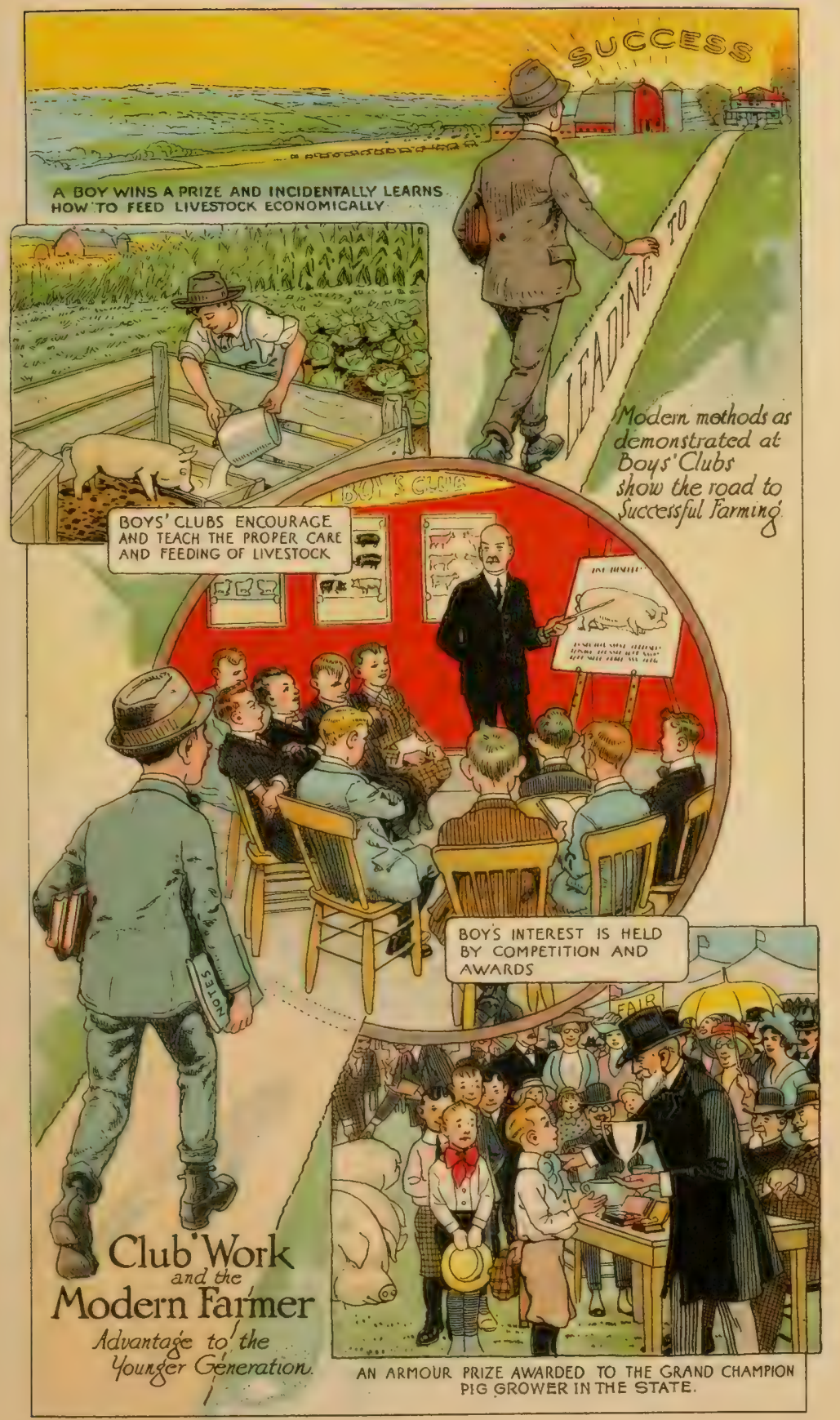




\section{SOIL FERTILITY AND LIVESTOCK FARMING}

The soil, in order to serve man's needs, must first grow plants, and these must be used directly by man, or made into many useful things, or fed to livestock, and in this way indirectly used by man. The minerals in the soil must be converted into organic matter by plants before they can be used by man or beast. The first step in agriculture is naturally the successful growing of plants, or field crops. We should never lose sight of this fundamental fact in our study of agriculture. The soil is the most important part of the whole matter, because everything must come from it.

The degree of fertility in the soil determines the degree of success that comes to the farmer, other things being equal. The mineral elements in the soil, commonly known as plant food, are so delicately balanced that a man, through careless methods, may cut down very rapidly the producing power of the soil. By a process known as "mining" the soil, one can in a very short time reduce the most fertile spot to a condition of poverty, and Dr. Bailey, of Cornell, rightly says: "Man will never gain dominion over the earth until he learns from nature how to maintain the augmenting powers of its disintegrating crust."

One great advantage in livestock farming is the ease with which soil fertility can be maintained by this method. There is always a place for every pound of surplus feed and grass and hay grown on the farm. When the livestock is shipped from the farm, much of the feed is left in the form of manure. To produce a hundred pounds of beef requires about 1,000 pounds of grain and 500 pounds of roughage. But of this, 1,400 pounds are left on the farm when the other hundred are sold. To grow a pound of mutton requires about nine pounds of feed, but eight pounds of this are left on the farm when the sheep is sold. With hogs it takes from four to six pounds of feed to produce one pound of flesh, but from three to five pounds are left on the farm when the hog is sold off. It will thus be seen that livestock encourages us to apply to our soils, in the form of manure, a large part of what grew on them, and these manures help to keep and increase the vitality of the soil. They help to increase the yields, and to cut down overhead expense.

Industry, and especially the packing industry, has an interest in the permanence of soil fertility because on no other basis can farmer and factory man thrive. A fertile soil means larger crops, and larger crops mean more and better livestock. This, in turn, means a busy manufacturing center, and more and better food for humanity.

Fertility may be maintained or increased through a good system of tillage, by emphasizing the livestock features of the farm, by the proper use of fertilizers or manufactured plant foods, and by a good system of crop rotation, that will leave the soil in a healthy condition. The farmer has the most sane and natural of all occupations and unquestionably finds life sweeter than any other class of citizens. At certain seasons he finds his life full to overflowing, but his patience is always tempered with the wonderful repose of nature, and his work is, or should be, always interesting. 


\section{FARMING MUST BE MORE ATTRACTIVE AND PROFITABLE}

The chief factor in making agriculture permanent is that the social, educational, recreational, and business opportunities shall equal those of the city or town. Farming must become sufficiently profitable that the farmer can reasonably expect to amass as much wealth as his fellows of the city. If this opportunity does not exist the number of farmers will continue to decrease and the type of men left in this industry will not equal those that have brought the American farmer to his present high status of leading the globe from the standpoint of per capita output. Progressive evolution in agriculture probably means that the unit of production must develop sufficiently to make a specialization in labor possible that will compare favorably with that of other industries.

The farmer's life offers the greatest opportunity for expression of individuality that exists in any vocation. Matters of personality, of efficiency, and of organizing and business ability are more directly expressed in the returns he receives and in the direct sense of accomplishment he experiences than in any other line of endeavor. The man who is alert, quick, wide-awake and observant, is more completely appreciated than in any other industry, for he must discover his needs and gain his rewards through close association with each of the manifold phases of Nature. There is no one to tell him the things to do except himself, and his direct measure of his own results are the chiefest of his rewards.

Nevertheless many improvements in the housing and social conditions of the farm must take place. The standards of the city with its home conveniences and labor-saving devices must be made available to the housewife and her family. Their need for companionship must be met by improved social conditions.

The war developed a very fallacious argument in many branches of industry through the assurance of cost of production plus a certain profit on government war contracts. It has given many industries, not excluding farming, the idea that they are entitled to a profit on everything they do regardless of their efficiency or the demand for their product. The old economic fact that profits do not come unless a demand for products exist, is ignored.

It is only by treating agriculture as a national industry run along strictly business lines, that the necessary profits will be assured. The growing of crops must be co-ordinated with the demands for farm produce, just as a manufacturing concern adjusts its output to the growth of its sales organization. The great disadvantage is that agriculture is organized on the small unit basis, but with the proper study of the problem, and with a constantly growing intelligence among the farmers, organization will be as feasible as anywhere in our citizenship. Farmers will then confer oftener with the industries so closely related to their business, and understand the problems as a whole rather than merely as the problems of the farmer. 


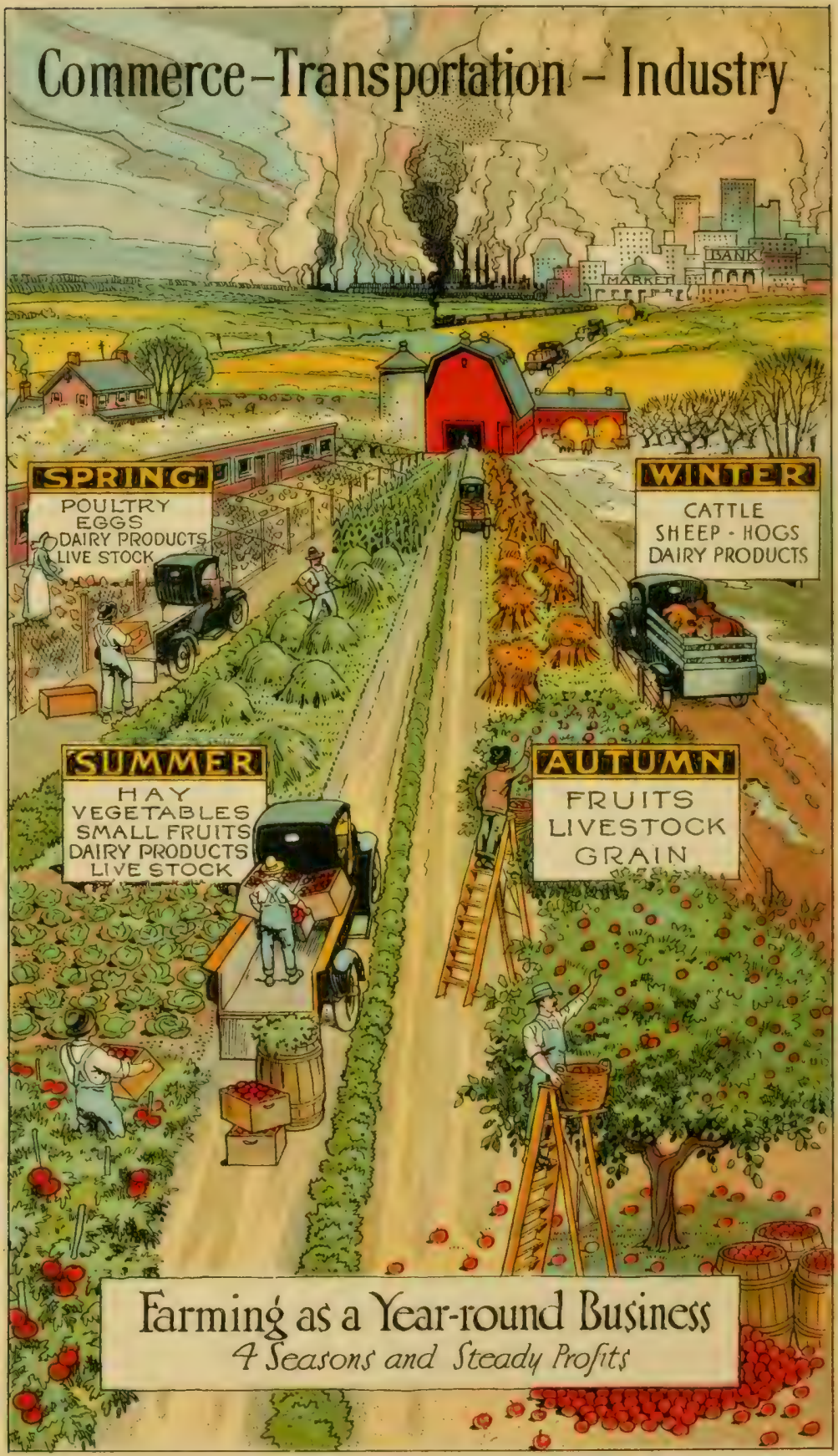




\section{FARMING AS A YEAR-RÖUND BUSINESS}

The successful operation of a packing house requires a staff of trained workers thoroughly familiar with every detail of what they should do, and a variety of well managed departments each with. its own special responsibility. It necessitates full operation every working day in order to distribute the overhead expense and to have available the kind of workers needed for each operation.

Farming as a business differs from the packing business only in the kinds of work. The same theories for efficiency in operation apply to the one as well as to the other. It is necessary for each farmer to have a variety of crops, or farm departments, from which he may secure employment for his laborers the year round, a reasonable profit with which to overcome the losses that are always likely to arise, and a progressive utilization of his own time to demonstrate his worth as a manager. The farm that is producing best is the one on which the farmer gives his operations continued and careful study, and has so organized them that the service rendered by himself, his laborers, and his acres is the greatest possible. Corn, wheat, oats, pastures, wood lots, fruit, poultry, cattle, hogs, sheep, garden produce, and so on, cost much in foresight, time, and money; but each, properly handled, adds to the year's income and bears its share of the labor and operating costs.

If for no other reason than the maintenance of a competent staff of workers, the farm owner should develop his operations on the yearly basis. The packing industry would be impossible unless it held its skilled workers throughout the year; but it could not do this unless it were able to give full-time employment. This experience is common to all lines of business, and the farm is no exception. How frequently one discovers in rural communities that a good man will find an appreciative employer until the corn is picked, the cotton marketed, and so forth, and then that he is turned adrift until the next cropping season opens.

Factories, stores. and offices in general follow a set schedule of hours, in order to maintain discipline and routine, and also in order to provide a common period for the transaction of business with all other business houses. The farm, on the other hand, works largely within itself. The farmer's work is more commonly by the job than by the hour. It is not a question of working until the whistle blows, but it is necessary to get the hay stacked or the grain threshed. The farmer and his men work more as the executives and their assistants in a big business, doing things when they need doing, regardless of time or personal inconvenience, and resting or taking recreation when things are not so pressing.

The good farm manager realizes these differences as compared to the kind of work required of the city laborer, and makes his men appreciate it as well. He rarely asks long hours unless they are necessary, and when he does he experiences little difficulty in getting the needed response. Farm work contains less of routine and dullness than office work, and considerably more which challenges the interest and enthusiasm of the ambitious person. Every farmer who has recognized this fact has successfully used it. 


\section{POWER ON THE FARM}

American farmers have set a standard of production per capita far above that of any other nation, because of their intelligent use of power. In no other country are more horses utilized per farm laborer than in America, and nowhere else are there such large farm investments in gas engines, windmills, automobiles, gas and steam tractors, and electric motors. The great concentration of power that has become possible in a single piece of motor machinery has enabled vast increases in production, although the extent of its utilization is even now little realized.

At present the horse furnishes about $75 \%$ of the power for breaking, cultivating and hauling, and the market for $24.5 \%$ of the corn, $67.8 \%$ of the oats, $17.7 \%$ of the barley, $26.5 \%$ of the rye, $5.4 \%$ of the wheat, $44.6 \%$ of the hay, $1.7 \%$ of the silage and $5.6 \%$ of the mill feeds. The future place of the horse in our agriculture will no doubt be related in some way to the share of concentrates which can be spared to feed him.

Farmers are beginning to discover the proper balance between horse power and mechanical motive power. The principal facts are presented in Farmer's Bulletin 1093, 1919, by the U. S. Department of Agriculture. Studies were made on $191 \mathrm{farms}$ averaging $3461 / 2$ acres, well distributed over the corn belt, on which tractors had been in use at least a year or over. The number of horses necessary to maintain on the farm was governed by the number necessary to cultivate the crops, and not by the number necessary to do the plowing, as was the case previous to the tractor. This made it possible to reduce horses from an average of $93 / 4$ per farm to $71 / 4$ animals. It also increased the number of acres possible to till per horse from $261 / 2$ to $381 / 2$. The actual increase in cultivated land over that tilled previous to the purchase of the tractor, was $8.03 \%$ and the average increase in the size of farms was 22 acres, or $6 \frac{1}{3} \%$. Nevertheless, the power requirements were such that only $4.7 \%$ of the farm operators were able to totally displace horses from plowing, and only $8.4 \%$ were able to allow their horses to stand idle while the tractors were in operation. This, then, gives an initial idea of the balance of the motor and the horse on the farm.

Along with more power on the farm comes the ability to modernize the country home, and, as the standards of the farm are continually being raised, to have more home conveniences, a higher degree of sanitation, and to find more time for recreation.

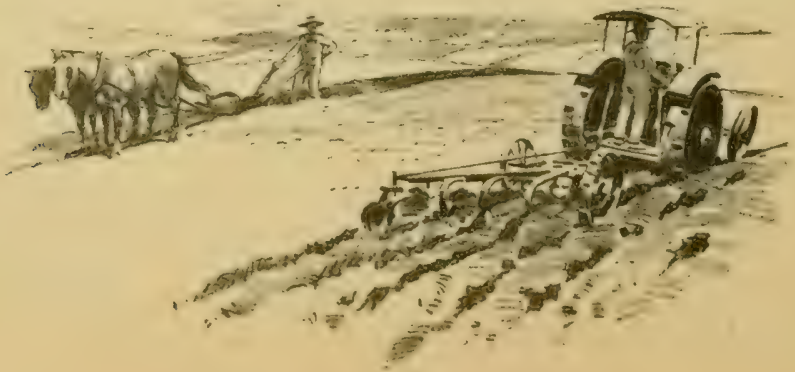




\section{STANDARDIZATION ALL ALONG THE LINE}

When anyonesays, "It Floats," "Spearmint," or "The Ham What Am," products are suggested that are not only advertised nationally, but which the above slogans describe as tried and true. Before a product can be marketed in a large way over vast territory, the raw material from which it comes, the manufacturing processes, the shipping packages, and the name must be controlled and standardized so that uniformity of product will result.

Standardization helps to promote honesty in business. It is a vital link in the chain of marketing that binds the seller to give an honest product and gives the buyer the assurance that he will receive an article of the usually accepted standard quality.

The application of this principle to farm products will mean as much to the farmer as it does to any other business project. For instance, it is well known that a mixed load of livestock containing a number of different grades does not sell as well as a uniform load. If some of the stock is well finished while others are thin, much more skill is required to estimate what the whole is worth, and often the farmer does not get the best bid that would be forthcoming.

Take the case of milk or cream. In all sections a higher price is paid for sweet cream than for sour, and frequently there are two or more grades of sour cream with corresponding prices. Hay is valued according to kind and quality; alfalfa is worth more than timothy; musty hay is worth less than sweet, well cured hay.

Eggs are subject to wide variation in value, depending upon quality. A mixture of whites and browns, large and small, dirty. and clean, sound and checked, or fertile and infertile eggs certainly bring a much lower price than good, clean fresh eggs of uniform size and color, or than the same lot properly graded and packed.

In a factory, standard articles can be prepared only by means of standard methods and standard machinery. For instance, meat curing processes require a certain length of time, a definite temperature, and exact proportions of ingredients that are used in making the curing solutions.

Likewise, standardized methods in farming operations are required to give the best results. Well selected seed corn of good quality will not produce standard results on an infertile soil, neither in yield nor true type. All grains, livestock, and other crops must be subjected to careful standardization from beginning to end, in order that the best product and highest prices may be obtained.

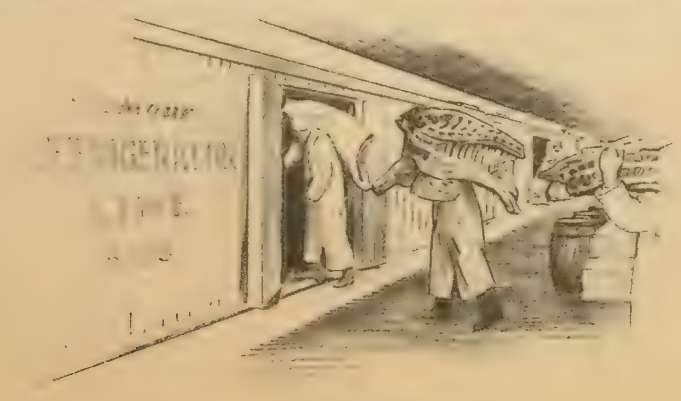




\section{CLUB WORK AND THE MODERN FARMER}

A portion of this handbook is devoted to the improvement of farm crops. In this chapter we are thinking of the best and most precious crop of all - the boys and girls on the farms of America.

There are twenty million boys and girls growing up in our rural communities. They are the greatest asset of the nation. A large percentage of these boys and girls would not have the inspiration for progress brought to them were it not for the Junior Club movement which is being carried on by agricultural extension agents under the supervision of the United States Department of Agriculture.

The fundamental principle underlying the success of club work is that the club member demonstrates to himself, his parents and his neighbors the value of better farm practices. Besides keeping the young people busy thinking of constructive things, it makes them assume responsibility; it instills business principles; it makes for progress by creating the spirit of competition; it keeps the young folks on the farm; it broadens their education, and because it does all this, it advances our agricultural industry.

One of the boys who won an educational prize trip provided last year by this Bureau had made $\$ 4,000$ on Angus cattle in three years, besides carrying his regular school work; another has accumulated $\$ 3,000$ worth of Berkshires; still another showed the Grand Champion Poland China sow in his State, winning out in the open classes over all the breeders. Selected from one million contestants, 350 champions visited Chicago and its prircipal points of interest during the week of the International Livestock Exposition in December, 1920, seventy-seven State Champions of this number from 23 States having been provided for by this Bureau.

Club work prevents the development of local prejudice and narrow viewpoints in the farm boy. In October, 1920, the winning stock judging teams from the club workers of 14 states assembled at the Southeastern States Exposition, at Atlanta, to contest for a trip to Great Britain during the 1921 show season. Every boy there had opportunity to learn of the manly qualities of his rivals and the seriousness of the problems which the farmers of each state face. Nothing can more quickly develop a spirit of co-operation and understanding than such association, while the opportunities of the winners to understand world problems is invaluable.

This contact of the business of farming with other business agencies, the learning and applying of agricultural fundamentals at an early age, the companionship developed in rural life because of this work and the advances made in agriculture under the stress of competition in Junior Club work, make it one of the most important branches of agricultural extension service.

This work has our support and indorsement in the belief that it will speedily bring about a more comprehensive understanding of the agricultural and livestock possibilities of the country and of the agencies which must function co-ordinately in order to make the growth of the agricultural industry a certainty. 


\section{FARMERS' ORGANIZATIONS}

The Armour organizations are frequently asked what their attitude is toward farmers' co-operative organizations. There are many reasons why we favor farmers' organizations which are estab. lished for the fundamental progress of agriculture. The underlying reason for our belief in them is that anything which helps the farmer makes for the prosperity of the entire nation.

The past history of farmers' organizations shows that they have been formed for widely varying purposes. Some have been organized for buying and marketing in quantity; others for the fraternal and social features alone; still others for the purpose of improving and enlarging the production of all farm products; and a few have affiliated for the sole purpose of influencing Congress to put through legislation favorable to the industry.

Some of the more recently launched organizations are planning their activities along most, if not all, of these lines. That organization which has for its purpose the working out of economic laws and their application to the problems of production and marketing, which combines the improvement of rural social life with business, which promotes an improved and efficient agriculture, which studies cost of production, which examines world markets that influence supply and demand; which avoids partisan politics and which in all its dealings is essentially fair toward all other classes of society; that organization, in our opinion, will prosper, endure, and render a great service to all peoples. If, however, a farmers' organization exists for the purpose of securing a good profit for all its members, be they aggressive or shiftless, producers of large yields or of small, real agriculturists or land miners, that organization, in our judgment, is doomed to failure.

The Armour organizations stand ready to confer and discuss with farmers' organizations the problems confronting both, and to co-operate with them in working out plans which will be beneficial to the upbuilding of the livestock industry as a whole. It is our belief that if producers organize for economic advantage, they must expect to pass the test to which every organization now in existence is subjected, the test of genuineness of service, ability to withstand competition, and efficiency of operation. We do not believe producers entering the field of marketing are entitled to more consideration than any other marketing agency, nor do we believe that their organizations need more than an equal chance. To organizations with such aims we extend our recognition.

In discussing these problems with farmers, our desire is to be recognized as reasonably well informed on the marketing problems, the manufacturing of livestock into meat and other products, and the wholesale distribution of these products. The best thought of all of the agencies which play a part in the production, manufacture, distribution, and consumption of livestock and all agricultural products, it seems to us, will be needed to make effective progress and to reach conclusions which will be equally fair to all, conclusions which will permanently strengthen the chances of farmers' organizations for achievement and success. 


\section{ACTIVITIES OF THE BUREAU}

The work of Armour's Bureau of Agricultural Research and Economics falls into four classes: a study of the economic relationship existing between this industry and production agencies; research and investigation of the packing industry, and of certain vital problems which retard the growth of the livestock industry, relations with producers and agricultural extension work.

The demand of most peoples for meat foods, the desirability of using livestock for converting hays, roughage, and grains into human food; the necessity of maintaining soil fertility, have all been mighty economic factors in shaping the agricultural destinies of the world and are but a few of the great economic principles with which this Bureau hăs been concerned in an effort correctly to guide company policy in all matters agricultural:

Special difficulties arise from time to time to hinder the normal progress of the livestock industry. Such questions as diseases and epidemics, the effect of by-products on meat prices, the influence of one class of meat upon the value of another, and many similar problems bearing directly upon the growth of the industry have received careful consideration and all the available information at hand, especially marketing information, has been published and passed on to the livestock producer.

It is our sincere purpose to develop the closest possible relationship with all primary producers, their organizations and other agencies established for the betterment of agriculture. Every branch of the livestock industry has its peculiar trials and difficulties. By comparing notes, it may be that each branch can help the other to eliminate these drawbacks. Public meat cutting demonstrations showing the most valuable type of animal from the standpoint of market demand; participation in farmers' and stockmen's meetings; the receiving of various organizations that desire to study packing house operations and practice; and exhibitions at many State fairs, are some of the means which this Bureau has used to develop this relationship.

In our agricultural extension work our aim is to aid the already organized extension forces by furnishing schools as well as producers condensed, practical literature on agricultural subjects, particularly from the market standpoint, by fostering Junior Club work, and by the exposition of better farm practices in State Fair exhibits. In this kind of work we are not competing with agricultural educational forces, but are supplementing their work by showing how science is being put to test in an extremely practical way. We are trying to interpret and measure values in the manufacturing places and in the homes of consumers, and are helping to compare these with estimated values in the feed lots and on the farms.

In all these activities it has been our desire: first, to understand the difficulties and problems of production; second, to understand the problems of packing; third, and greatest of all, to bring about a mutual understanding, the one of the other. As the contact point, this Bureau aspires to bring about and maintain the proper relationship that should exist between the producers and Armour. 


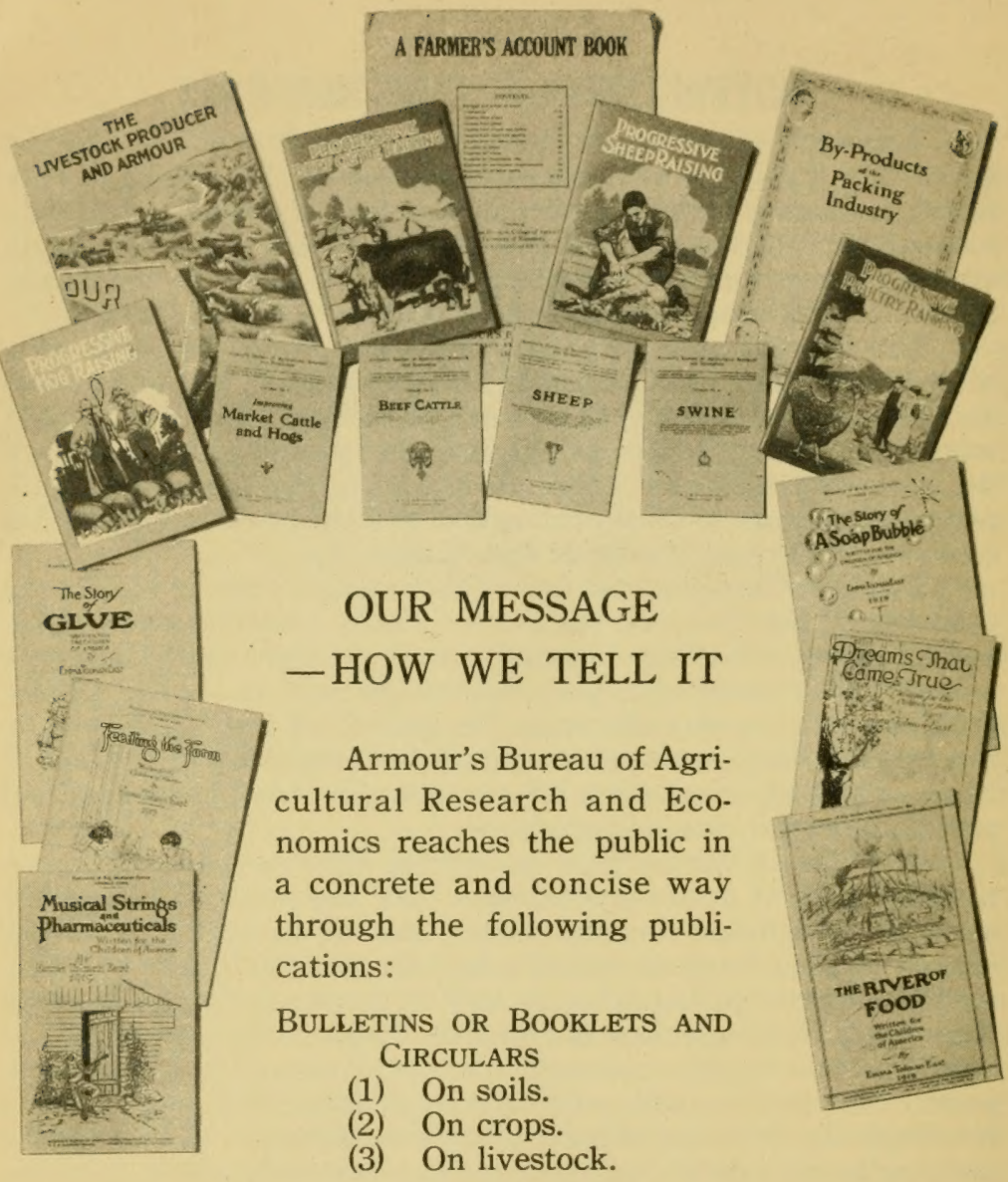

MONTHLY LETTERS

(1) To county agents reflecting the barometer of the meat and livestock situation, also our relations to agriculture.

(2) To Animal Husbandmen and livestock experts, giving a scientific interpretation of many phases of this industry in its relation to agriculture.

LANTERn Slides AND Moving Pictures, reflecting the economics of the packing industry, and the relation of the industry to improved agriculture. We have done only a limited amount of this work up to the present time.

The actual placing of improved livestock in certain parts of the country, and creating interest in club work in this way.

PRESS ARTICLES, showing the value of improved agriculture and improved types of livestock as reflected in the market places.

State Fairs, International Live Stock Exposition.

BOYS and GiRLS CLUB WORK. 
, :.

MUN 1 1 992 I 
